\title{
Effect of thermocycling in a hard denture liner and acrylic resin after different chemical and mechanical polishing
}

\author{
Efeito da termociclagem em reembasador rígido para prótese e resina acrílica após polimento químico e \\ mecânico
}

Graziella Morfim Schramm ALIGNANI ${ }^{1}$

Juliana Maria Costa Nuñez PANTOJA²

Jessica Mie Ferreira Koyama TAKAHASHI ${ }^{2}$

Andréa Araújo de VASCONCELLOS 3

Marcelo Ferraz MESQUITA²

Milton Edson MIRANDA'

\section{ABSTRACT}

Objective

To evaluate the effect of aging in a hard denture reline (New Truliner) and an acrylic resin (Classic) after chemical and mechanical polishing

\section{Methods}

Eighty specimens were made, divided randomly between 8 groups: $G_{1}$ Acrylic Resin Classic (RAC)/Mechanical Polishing (PM); G $R A C / P M+$ thermocycling (TR); G) RAC/Chemical Polishing (PQ); G RAC/PQ + TR; G New Truliner (NT)/PM; G NT/PM + TR; G NT/PQ; G NT/PQ + TR.

The surface hardness was measured before and after polishing, and after TR. The impact resistance tests were measured after all applied treatments. The data were submitted to ANOVA and Tukey test $(\alpha=5 \%)$.

\section{Results}

Regardless of the polishing, it was noted that RAC presented significantly higher surface hardness than NT; PM had higher hardness in both materials compared with PQ; on both polishing, the impact resistance of the RAC was higher than NT. Independently of TR test, the impact resistance of the materials that received $P Q$ was higher than received $P M$. The $P Q$ caused greater changes in properties than the PM.

\section{Conclusion}

Aging and chemical and mechanical polishing influenced the physical and mechanical properties of hard denture reline and acrylic resin.

Indexing terms: Acrylic resins. Aging. Denture liners. Hardness.

\section{RESUMO}

\section{Objetivo}

Avaliar o efeito da termociclagem em reembasador rígido para próteses totais (New Truliner) e resina acrílica (Clássico) após polimento químico e mecânico.

\section{Métodos}

Foram confeccionados 80 corpos de prova, divididos de forma randomizada entre 8 grupos: G Resina Acrílica Clássico (RAC)/Polimento mecânico (PM); G RAC/PM + termociclagem (TR); G RAC/Polimento químico (PQ); G RAC/PQ + TR; G New Truliner (NT)/PM; G NT/PM + TR; $G_{7}$ NT/PQ; $G_{8}$ NT/PQ + TR. A dureza superficial foi mensurada antes e após os polimentos, e após a TŔ. Os ensaios de resistência ao impacto foram mensurados após todos os tratamentos. Os dados foram submetidos à análise de variância e Tukey $(\alpha=0,05)$.

\section{Resultados}

Independente do polimento verificou-se que RAC apresentou resultados de dureza superficial significativamente mais altos que NT; PM gerou superfícies mais duras em ambos os materiais quando comparado ao PQ; em ambos os polimentos, os valores de resistência ao impacto da RAC foram maiores que os do NT. Independentemente da realização da TR, a resistência ao impacto dos materiais que receberam PQ foi maior que a dos que receberam PM. PQ causou maior alteração nas propriedades do que PM.

\section{Conclusão}

A termociclagem e os polimentos químico e mecânico influenciam as propriedades físicas e mecânicas do reembasador rígido e da resina acrílica.

Termos de indexação: Resinas acrílicas. Envelhecimento. Reembasadores de dentadura. Dureza.

\footnotetext{
${ }^{1}$ Faculdade São Leopoldo Mandic, Curso de Odontologia, Programa de Pós-Graduação em Prótese Dentária. Rua José Rocha Junqueira, 13, Swift, 13045-755, Campinas, SP, Brasil. Correspondência para / Correspondence to: AA VASCONCELLOS. E-mail: <andrea.odonto@yahoo.com.br>

2 Universidade Estadual de Campinas, Faculdade de Odontologia. Piracicaba, SP, Brasil.

${ }^{3}$ Universidade Federal do Ceará, Curso de Odontologia. Campus de Sobral, Centro, Sobral, CE, Brasil.
} 


\section{INTRODUCTION}

The oral rehabilitation of total or partial edentulous patients is usually performed through partial or complete removable dentures, overdentures and implant supported fixed prostheses, and the acrylic resin is often used for making the base of these prostheses' ${ }^{1}$.

The acrylic resin thermally or chemically activated is the material of choice considering the very satisfactory properties such as low cost, does not require sophisticated equipment for the use, and is easily manipulated ${ }^{2}$. Also, the resins must have adequate strength and resilience, as well as resistance to compression or to masticatory forces, impact forces by accidental drops and by excessive wear caused during hygiene techniques ${ }^{2}$. The material must also be dimensionally stable under all conditions of use, including changes in temperature and load variation ${ }^{3}$.

Despite the favorable characteristics, it can occur an improper seating of the prosthesis in the soft tissue due to the physiological bone resorption that occurs progressively ${ }^{4}$. Consequently, it can result in a gradually loss of retention and stability of the prosthesis, important for patient comfort and preservation of supporting tissues. In those situations, relining procedure must be considered. The relining of complete and partial removable dentures is a process in which a plastic material is added to the inner side of the prosthesis to enhance adaptation to the mucosa, and can be performed by two techniques: clinical or direct reline, and clinical and laboratory reline or indirect ${ }^{5}$.

The direct relining can be performed with materials directly used in the oral cavity ${ }^{5}$. For this, autopolymerized hard denture reline should be used, which may be rigid or resilient (soft). This technique has advantages in relation to indirect, such as easy and fast to be performed. By the other hand, these materials have different chemical compositions, and the final structure of the polymer may differ considerably, resulting in different clinical results ${ }^{6}$. In relation to the properties, some studies show that the direct relining have lower results compared to the conventional acrylic resins?

When the prostheses are submitted for intermittent or continuous exposure to chemical agents (food and beverages and chemical cleaning agents) and forces of chewing, can occur the degradation of these materials ${ }^{8}$. This degradation can cause microcracks on acrylic resins surface and can change their surface characteristics ${ }^{7}$. It is known that polishing for denture base acrylic resins can be performed mechanically or chemically ${ }^{9}$. Also, chemical cleaning agents can be used, but the use for a long period of time can cause changes in the physical and mechanical properties in the denture base ${ }^{10}$.

In order to simulate the clinical conditions of different materials in laboratory studies, the thermocycling has been used to simulate the degradation by accelerated aging of materials, varying the temperature and using humidity ${ }^{11-12}$.

Another important property of these materials is the impact resistance, which is a measure of how much energy is absorbed by the material when it is broken by a sudden knock. In this context, the denture base should have high impact resistance to prevent breakage by accidental drops ${ }^{13}$.

Generally, the procedures used to mechanical polishing of acrylic denture base resins include grinding wheels, felt cones, pumice powder and water ${ }^{13-14}$. In attempting to eliminate the steps of mechanical polishing, Gotusso ${ }^{15}$ described the steps of a technique known as chemical polishing. In this technique, the polishing was performed by immersion of the prosthesis for 1 minute in monomer heated in boiling temperature. Stolf et al. ${ }^{16}$ suggested an immersion of the prosthesis for 10 seconds in monomer heated in $75^{\circ} \mathrm{C}$.

It is known that changes in the soft materials surface may alter some physical properties. The chemical polishing promotes a smooth surface of acrylic resin by the action of the monomer, which can soften their surface and therefore reduce surface hardness. However, it is not known the effect of chemical and mechanical polishing on the surface of hard reline and aging by thermocycling. Thus, this study aimed to evaluate the effect of aging by thermocycling, and also the effect of chemical and mechanical polishing on the surface hardness and impact resistance of a hard denture reline for prostheses and a thermally activated acrylic resin.

\section{METHODS}

The samples were prepared with $64 \times 10 \times 3 \mathrm{~mm}$ corresponding to the length, width and thickness, respectively, using rectangular metal matrix which were molded by condensation silicone for laboratory use (Zetalabor, Zhermack, Rovigo, Italy).

Ten aluminum matrix composites were previously isolated with gypsum insulating (Cel-Lac, SS White Dental Articles, Rio de Janeiro, Brazil) and embedded in a metallic muffle $^{12}$. The lower part of muffle was filled with type III dental stone (Herodent, Vigodent, Rio de Janeiro, Brazil), under vibration, thus avoiding the occurrence of air bubbles in the gypsum. After gypsum crystallization (30 $\mathrm{min}$ ), on the surface previously abraded, the metal matrix composites 
were glued with cyanoacrylate adhesive (Loctite Super Bonder, Loctite Corporation, Brazil) and adapted the muffle to the counter muffle. It was added laboratory silicone (Zetalabor, Zhermack, Rovigo, Italy) on matrix to obtain a mold. Then, it was poured type III gypsum to carry out the complete filling of the muffle and counter-muffle. The muffle was closed and placed in the bench press for 1 hour. Then, the muffle was opened and the matrix removed, and the mold was printed on the laboratory silicone. Thereafter, the gypsum was poured and the set was isolated with CelLac according to manufacturer's recommendations.

For the preparation of the samples, the thermally activated acrylic resin (Classic, Articles Dental Classic Ltda, São Paulo, Brazil) was manipulated according to manufacturer in a volumetric ratio of 3 parts of polymer to 1 part of monomer. The mixture was carried out in a glass pot (JON Dental Products, São Paulo, SP - Brazil), always with saturation of the monomer by the polymer. In the plastic phase (15 to 20 minutes), the resin was distributed in the molds obtained in the muffle and pressed in an hydraulic press (EMIC, equipment and LTDA Test Systems, São José dos Pinhais, PR, Brazil), and then the muffles were adapted in spring presses. The muffles containing thermally activated acrylic resin were polymerized (Termotron P100; Termotron equipment, São Paulo, Brazil) with curing cycle by water immersion at $75^{\circ} \mathrm{C}$ for $9 \mathrm{~h}$, and then were removed and cooled on a workbench until it reaches room temperature. After this period, the samples were deflasked. It was fabricated 40 samples of acrylic resin.

To prepare the hard liner samples (New Truliner, Bosworth Skokie, IL, USA), it was used the proportion of a plastic bottle filled with powder and a glass bottle filled with liquid, and these bottles were provided by the manufacturer. The mixing was performed in a glass pot, obtaining the saturation of the monomer by the polymer for 30 seconds. Then, it was placed the cover in the pot and immediately poured into the muffle's mold, and pressed in a hydraulic press (EMIC, Equipment and Test Systems LTD, Sao Jose dos Pinhais, PR, Brazil). After $1 \mathrm{~h}$ in spring presses, the muffles were deflasked. It was fabricated 40 samples of hard liner.

After the deflasking, it was used in all samples abrasive tips [maxi-cut drills (Wilcos of Brazil, Petrópolis, RJ, Brazil)] with heavy duty cutting and immediatly light duty cutting. Afterwards, sheets of sandpaper with different grits (200, 400 and 600; Norton, Saint-Gobain, Vineyard, SP, Brazil) adapted to polishing machine (AROTEC, Cotia, SP, Brazil) were used to produce a smoothly polished surface. The samples were divided into eight groups, $\mathrm{n}=10$ (Table 1 ).
Table 1. Materials e treatments used.

\begin{tabular}{ccc}
\hline Group & Material & Treatment \\
\hline Group 1 & Acrylic resin classic & Mechanical polishing \\
Group 2 & Acrylic resin classic & $\begin{array}{c}\text { Mechanical polishing } \\
\text { +thermocycling } \\
\text { Chemical polishing }\end{array}$ \\
Group 3 & Acrylic resin classic & Chem polishing+ thermocycling \\
Group 4 & Acrylic resin classic & Chemical polishing \\
Group 5 & New truliner & Mechanical polish \\
Group 6 & New truliner & Mechanical polishing + \\
Group 7 & New truliner & Chemical polishing \\
Group 8 & New truliner & Chemical polishing+ thermocycling \\
\hline
\end{tabular}

For polishing, the samples were separated into two groups: mechanical polishing (A) and chemical polishing (B). a) The mechanical polishing was performed in bench polishing (Mod P121R, Nevoni, NSR ${ }^{\circledR}$ Ind. Com and Rep. Ltda., Barueri, Brazil). Initially, it was used a white brush number 30 , then a black brush number 29, and finally a felt-tip, all with pumice paste (Herjos- Vigodent SA Industria e Comercio, Rio de Janeiro, Brazil) and water. Final polishing was performed with a flannel wheel and Spanish white paste (K. Dent - Quimidrol, Joinville, Brazil) and water;

b) The chemical polishing was performed in a chemical polishing (model FP-9000; Termotron equipment, Piracicaba, Brazil), with liquid for polishing (PoliQuim, Clássico Artigos Odontológicos Ltda, Campo Limpo Paulista, Brazil) - conventional monomer with higher amount of stabilizer in order to prevent its polymerization after several polishing. The polishing was carried out by liquid immersion at $75^{\circ} \mathrm{C}$ for 10 seconds, according to the manufacturer's instructions. After polishing, the samples were stored in distilled water at $37{ }^{\circ} \mathrm{C}$ for $24 \mathrm{~h}$ in incubator ${ }^{14}$.

The samples that underwent to thermocycling had the following sequence of treatment: storage for 24 hours in distilled water at $37^{\circ} \mathrm{C}$, and thereafter in 270 thermal cycles ${ }^{17}$ in a thermocycler (MCT2 AMM Instrumental, Erios, São Paulo, Brazil), alternating baths of 1 minute in distilled water at $5 \pm 1{ }^{\circ} \mathrm{C}$, and 1 minute in water at $55 \pm 1{ }^{\circ} \mathrm{C}$, simulating the clinical use of the material for 3 months ${ }^{12}$. The samples were submitted to hardness test using a microhardness machine (HMV Model 2000, Shimadzeu, Tokyo, Japan), calibrated with a load of $15 \mathrm{~g}$ applied for 30 seconds. Each sample was subjected to 5 indentations in different regions of the surface before and after the 
polishing, and after the thermocycling. The data were converted into Knoop Hardness Numbers (KHN) values.

Resistance to impact was evaluated by Charpy test (OTTO WolpertWerke machine, Ludwighafen, On-Rhine, Germany; Charpy system) with a tip of $40 \mathrm{Kp} / \mathrm{cm}^{2}$, and 40 $\mathrm{mm}$ was the distance between the supports of the sample. The samples received the impact in the central region ${ }^{18}$.

The statistical analysis was carried out using SAS/ LAB software (SAS Software, version 9.1; Cary, NC, USA), and the data were transformated as suggested by the software to log10. Tukey's test was used for pos-ANOVA comparisons. This analysis was performed by SANEST statistical program, and the significance level $(\alpha)$ was $5 \%$.

\section{RESULTS}

The Table 2 shows the hardness results. According to the ANOVA, the triple interaction between the material $x$ polishing $x$ time was significant $(p<0.01)$, indicating a dependency relationship between the factors effect.

Table 2. Mean (standard deviation) of the Knoop Hardness Numbers (KHN) under the experimental conditions.

\begin{tabular}{|c|c|c|c|c|}
\hline \multirow[t]{2}{*}{ Material } & \multirow[t]{2}{*}{ Polishing } & \multicolumn{3}{|c|}{ Time } \\
\hline & & Baseline & After polishing & After thermocycling \\
\hline \multirow[t]{2}{*}{ Classic } & Mechanical & 15.5 (0.7) Aa* & $14.0(1.1) A b^{*}$ & 15.5 (0.9) Aa* \\
\hline & Chemical & 15.7 (1.3) Aa* & $6.4(0.7) B c^{*}$ & $11.0(2.6) \mathrm{Bb}$ * \\
\hline \multirow[t]{2}{*}{ New truliner } & Mechanical & $7.3(1.0) \mathrm{Aa}$ & $4.9(0.5) \mathrm{Ab}$ & $5.2(0.5) A b$ \\
\hline & Chemical & $6.6(0.9) \mathrm{Aa}$ & $0.4(0.1) B C$ & $5.2(0.7) \mathrm{Ab}$ \\
\hline
\end{tabular}

Note: Means followed by different letters represent statistical significance (ANOVA / Tukey, $\alpha=5 \%$ ). Uppercase letters compare polishing with the same material $x$ time; lowercase letters compare time considering the same material $x$ polishing; and $\left({ }^{*}\right)$ compares material with the same polishing $x$ time.

The Tukey's test showed that regardless of polishing or time, the Classic material had significantly higher hardness than the New Truliner. Differences between the polishing were observed for the Classic material after polishing and after thermocycling, noting that the mechanical polishing resulted in greater hardness than chemical polishing. Similarly to Classic material, New Truliner had higher hardness after mechanical polishing in relation to chemical polishing. However, after thermocycling, both polishing resulted in similar hardness to the New Truliner samples (Table 2).

Comparing the time evaluated, it is observed that the Classic material showed lower hardness after mechanical polishing compared to other periods (baseline and after thermocycling), although no statistically difference was noted. When the Classic samples underwent to chemical polishing, the baseline had the highest hardness, and the lowest hardness after polishing. After thermocycling, the samples showed intermediate values, however, different from other periods, and all periods were statistically different (Table 2).

Regading New Truliner, similar values of hardness were observed after mechanical polishing and after thermocycling, being significantly lower in relation to baseline. When the samples underwent to chemical polishing, there was significant differences in hardness in the three periods. The highest value was at baseline, and the lowest value was after the polishing; after thermocycling, intermediate values were observed, and all groups showed statistically significant diferences (Table 2).

The results of the impact resistance are shown in Table 3. The interaction between time $\mathrm{x}$ polishing $\mathrm{x}$ material was not significant $(p=0.86)$. However, the interactions between resin $x$ polishing $(p=0.002)$ and resin $x$ thermocycling $(p=0.01)$ were statistically significant. These interactions were demonstrated by the Tukey's test (Table 3 and 4).

Table 3. Mean (standard deviation) impact resistance in the experimental conditions.

\begin{tabular}{cccc}
\hline Material & Polishing & \multicolumn{2}{c}{ Thermocycling } \\
\cline { 3 - 4 } & & Absent & Present \\
\hline Classic & Mechanical & $6.4(0.56) \mathrm{Aa}$ & $7.3(0.89) \mathrm{Aa}$ \\
& Chemical & $7.3(0.8) \mathrm{Aa}$ & $\mathrm{Aa}$ \\
New truliner & Mechanical & $2.33(0.59) \mathrm{Bb}$ & $2.53(0.42) \mathrm{Bb}$ \\
\cline { 2 - 4 } & Chemical & $4.26(0.71) \mathrm{Bb}$ & $3.83(0.36) \mathrm{Bb}$ \\
\hline
\end{tabular}

Note: Means followed by different letters represent statistical significance (ANOVA / Tukey, $\alpha=5 \%$ ). Uppercase letters compare the material within each thermocycling; lowercase letters compare the polishing within each material. 
Regardless the thermocycling, the impact resistance of the materials after the chemical polishing was significantly higher than mechanical polishing. In both polishing, the impact resistance of Classic material was statistically greater than New Truliner (Table 4).

Table 4. Mean (standard deviation) of impact resistance according to the resin and polishing. Thermocycling factor data are grouped.

\begin{tabular}{|c|c|c|}
\hline \multirow[t]{2}{*}{ Material } & \multicolumn{2}{|c|}{ Polishing } \\
\hline & Mechanical & Chemical \\
\hline Classic & $6.85(0.83) \mathrm{A}$ & $7.51(0.78) A$ \\
\hline New truliner & $2.43(0.47) \mathrm{B}$ & $4.04(0.57) \mathrm{B}$ \\
\hline
\end{tabular}

Note: Means followed by different letters represent statistical significance (ANOVA / Tukey, $\alpha=5 \%$ ).

It was observed no differences between the impact resistance in New Truliner samples regardless the presence or absence of thermocycling. Similar results were found in Classic samples. However, the impact resistance of Classic material was statistically greater than New Truliner, independent of the presence or absence of thermocycling (Table 5).

Table 5. Mean (standard deviation) of impact resistance in relation to material and thermocycling. Polishing factor data are grouped.

\begin{tabular}{|c|c|c|}
\hline \multirow[t]{2}{*}{ Material } & \multicolumn{2}{|c|}{ Thermocycling } \\
\hline & Absent & Present \\
\hline Classic & $7.5(0.89) \mathrm{Ab}$ & $6.86(0.78) \mathrm{Aa}$ \\
\hline New truliner & $3.18(0.76) \mathrm{Ba}$ & 3.3 (1.16) Ba \\
\hline
\end{tabular}

Nota: Means followed by different letters represent statistical significance (ANOVA / Tukey, $\alpha=5 \%$ ). Uppercase letters compare the material within each thermocycling; lowercase letters compare the thermocycling within each material.

The correlation between impact resistance values and the values of surface hardness by the Pearson coefficient were performed, and it was found that there is a positive correlation $(p<0.0001)$ by BioEstat program 5.0. It was found that with increasing of hardness values of the material, higher impact resistance values were detected $[r$ (Pearson) $=0.6739$, and $(p)=<0.0001)]$.

\section{DISCUSSION}

The heat activated acrylic resins are widely used for confection of denture base, considering its satisfactory flexibility, friable to the impact and moderately resistant to fatigue failure ${ }^{2,13}$.

An important aspect to be considered is the surface roughness of conventional acrylic resins and hard denture reline resin. The importance of surface roughness is the fact that a smooth surface prevents the accumulation of biofilm, reducing the possibility of the occurrence of mucosal inflammation ${ }^{19}$ and plaque adhesion on these materials. However, although they are well made and polished, changes can occur over time in the surface of acrylic resin, resulting in microorganism accumulation. In this context, Candida albicans is the fungi more prevalent, difficult to be eliminate and more resistant ${ }^{20}$, and any irregularities in polishing of acrylic resins may allow the irreversible accumulation of cells and microorganism. Proper oral hygiene of the dentures with toothbrush and toothpaste are important factors for the clinical management of the material, and polishing the surfaces of the prosthesis is critical to avoid biofilm accumulation.

In the present study, it was observed that the surface hardness of the acrylic resin and the hard reline was lower after the chemical polishing. According Anusavice ${ }^{3}$ and Braun et al. ${ }^{21}$, chemical polishing probably dissolves the polymer chains in the polymerization of acrylic resins, decreasing its surface hardness. Likewise, Orsi \& Andrade ${ }^{10}$ affirmed that the use of chemical polishing could affect the structure and strength of the resin. A previous study ${ }^{22}$ observed a decrease in surface hardness values after chemical polishing, which agrees with the results of the present study, and also related an increase in the transverse deflection of the samples subjected to chemical polishing. Also in relation to surface hardness, after artificial aging, it was found that the materials had higher hardness compared to values obtained after polishing. However, the hardness after the chemical polishing was lower than mechanical polishing, assuming the same phenomena previously described.

The hard reline material used in this present study has in its composition the plasticizer isobutyl methacrylate, di-n butylphthalate ${ }^{23}$ and toluidine ring, which acts as an activator of the chemical reaction of polymerization ${ }^{24-25}$. Although this material has no cross-chain agents, these molecules can fill the voids and, thereby, reduce the water absorption ${ }^{24}$. It is possible to hypothesize that the thermally activated materials have a higher degree of polymerization, resulting in larger amount of monomer converted to polymer in relation to the chemically activated, that have higher amounts of residual monomer ${ }^{14,24-25}$. The amount of residual monomer may adversely affect the mechanical properties, such as hardness and tensile strength ${ }^{26-27}$. In view of this, heat activated materials have greater resistance to the effects of the monomer used for the chemical polishing ${ }^{14}$. This situation may result in a greater effect of the monomer on the chemically activated resin (hard reline) in comparison with the heat-activated acrylic resin and, consequently, it is observed lower surface hardness values. The hard denture reline with cross polymer chain and the 
resins that have mainly polymethyl methacrylate and methyl methacrylate have greater resistance to transverse flexion and modulus of elasticity in relation to other reline resins ${ }^{27}$. This increase in resistance reveals an advantage that may exist when cross chain agents are added to chemically activated resins ${ }^{23}$, but were not the hardness values found in this study. The use of crosslink agents promotes greater surface resistance to small fractures, cracks calls, and may decrease the solubility and water sorption, but has little effect on the tensile strength, the transverse properties or hardness of acrylic plastics ${ }^{13}$.

According to Goiato et al. ${ }^{28}$, the samples that were mechanically or chemically polished had similar values of surface porosity when analyzed after thermocycling. These authors stated that the simulated aging may have removed the most superficial layer of samples that were chemically polished, homogenizing the groups with statistically similar results. Similar results can be observed in the present study, when analyze the probably removal of this surface layer of samples that had chemically polishing. The surface hardness levels were reduced after the chemical polishing, and increased values were found after thermocycling for both materials. However, the groups were not homogenous when comparing the polishing after thermocycling for conventional acrylic resin; this post-thermocycling homogeneity was only obtained for the hard reline material. The difference in surface hardness values of the materials investigated may result from the difference between the levels of residual monomer, considering the different polymerization technique (chemically and thermally activated) ${ }^{14,23}$.

According to Machado et al. ${ }^{14}$ and Rahal et al. ${ }^{29}$, the chemical polishing uses heated monomer, which attacks the surface of the resin acting as a plasticizer. Thus, can result in a weakening of intramolecular forces and break the crosslinked polymer chains through the large accumulation of non-reactive substances in the superficial region, causing higher solubility of the material. This process can cause a superficial softening, justifying the values obtained in this study. The absorption of water acts as a plasticizer, altering the mechanical properties of the materia|23,25. This may explain the post thermocycling results, which probably resulted in water absorption, and partial removal of the residual monomer, detecting increased surface hardness values.

The changes in molecular structure of the polymer as a result of the aging process has been attributed to the following factors: scission of the polymers chains (cisão das cadeias dos polímeros ) caused by ultraviolet light; intersection on oxygen chain (cruzamento em cadeia de oxigênio) and water absorption ${ }^{17}$. The thermal effects of the intake of hot and cold food can be one of the major factors affecting the characteristics of these polymers used for making the base of removable prostheses ${ }^{1}$ and also the hard reline ${ }^{6}$. In addition, a previous study ${ }^{30}$ reported that accelerated aging can affect the physical and mechanical properties of many elastomers used as prosthetic denture reline, occuring an increase in hardness values, confirming our results. The surface hardness values are of great relevance to the material used for the confection of prosthesis, because the material undergone by cleaning techniques as well as damage caused by food and chewing cycle.

Considering the impact resistance, it was found higher values in both resins submitted to chemical polishing, regardless the thermocycling, although the triple interaction (material $x$ polishing $x$ time) was not significant. This may be attributed to the monomer of chemical polishing, that causes changes in the structure of the material and, consequently, make them with less hard surface and more flexible, while the mechanical polishing showed no structural changes, keeping them more friable.

Further, the impact resistance of the materials that had chemical polishing was significantly higher in relation to samples with mechanical polishing regardless of thermocycling, which results are in accordance with a previous study ${ }^{16}$. Considering that the acrylic resin chemically activated had higher residual monomer in relation to thermally activated, the samples had a lower impact resistance. Probably, this is due to the greater presence of residual monomer in the hard reline resin. According Anusavice ${ }^{3}$ and Rodrigues et al. ${ }^{27}$, the residual monomer reduces the mechanical properties of materials, being responsible for the formation of internal pores that concentrate tensions when this resin is subjected to a load.

The autopolymerized hard reline showed significantly lower flexural strength than thermopolymerized acrylic resins. This may be related to the plasticizing agent and to the powder of the high amount of residual monomer ${ }^{7,27}$. The nonreactive monomers act as a plasticizer and decrease the mechanical properties of methacrylate polymers ${ }^{27}$. According to Craig \& Powers ${ }^{13}$, although the addition of plasticizer can increase the strength of plastics in the occurence of impact, this increase is accompanied by a decrease in hardness, in modulus of elasticity and in compressive strength, supported partially by the results of this research.

Comparing the hardness values and the impact resistance results showed in the presente study, it can be assumed that samples with higher surface hardness 
values have more impact resistant, differing from another studies, such as Archadian et al. ${ }^{17}$ and Arima et al. ${ }^{23}$. This result may have been influenced by the size and type of the samples. The values found can be justified by the physical characteristics of both autopolymerized and thermopolymerized acrylic resins. These materials have high surface hardness values, although these values are lower in relation to surface hardness of glass or ceramic. However, these values of acrylic resin allow to achieve a high value for impact resistance, although they are not so high as the most resilient materials.

When analyzing the samples of thermoactivated acrylic resin, it was observed higher impact resistance after thermocycling (regardless of polishing), when compared to samples that were not aged, even with higher values of surface hardness. Probably, thermocycling significantly alter the structure of acrylis resin chains that makes them more resistant to impact, even with high hardness values. These findings differ from studies of Archadian et al. ${ }^{7}$ and Finoti et al. ${ }^{25}$, that the denture base resin polymer had a flexural strength decreased after thermocycling, suggesting that this result is due to the solubility of residual monomer and to stress caused by heat, which caused higher water absorption and consequently greater distance between the polymer chains.

The increase in impact resistance obtained by Classic resin, which mainly contains polymethyl methacrylate and methylmethacrylate, compared with the New Truliner, which has no cross-chains, but has the plasticizer di n-butylphthalate in $8 \%$ of its composition, revealed no advantages in the addition of cross-chain agents to the monomer of autopolymerized resins ${ }^{23}$.

The results of polishing groups were grouped and, therefore, probably result in this difference regarding the presence or not of thermocycling. Comparing with the results regardless of thermocycling, the impact resistance of the materials with chemical

\section{REFERENCES}

1. Lynch $C D$. Successful removable partial dentures. Dent Update. 2012;39(2):118-26.

2. Gautam $R$, Singh RD, Sharma VP, Siddhartha $R$, Chand $P$, Kumar R. Biocompatibility of polymethylmethacrylate resins used in dentistry. J Biomed Mater Res B Appl Biomater. 2012;100(5):1444-50.doi: 10.1002/jbm.b.32673

3 Anusavice KJ. Phillips, materiais dentários. Rio de Janeiro: Editora Elsevier; 2005. polishing was significantly higher. The use of chemical polishing can provide better impact resistance, but the mechanical polishing ensures a higher hardness value. The chances of fractures from accidental falls is reduced in the porportion of the higher impact resistance of the material. Thus, the materials used for the prosthesis confection must have high value of impact resistance.

The values obtained in this study may be influenced by the size of cross-linked of the materials tested. So, more studies should be conducted, considering that occurred a positive correlation between hardness and impact resistance. In other words, with increasing of hardness values of the material, higher impact resistance values is detected.

Laboratory studies are very important as information sources for evaluating physical and mechanical properties of materials, but further clinical studies are of utmost importance, since the behavior of these materials is influenced by clinical factors and their reproduction in the laboratory is limited.

\section{CONCLUSION}

Within the limitations of this study, it was concluded that the hard denture reline showed lower values of surface hardness and impact resistance when compared to thermopolymerized acrylic resin; the chemical polishing resulted in greater change in the properties of the materials studied in relation to mechanical polishing; and thermocycling caused structural changes in both materials, changing its physical and mechanical properties.

\section{Collaborators}

GMS ALIGNANI, JMCN PANTOJA, JMFK TAKAHASHI, AA VASCONCELLOS, MF MESQUITA, ME MIRANDA participated in all stages of preparation of the manuscript.
4 Tallgren A. The continuing reduction of the residual alveolar ridges in complete denture wearers: a mixed-longitudinal study covering 25 years. 1972. J Prosthet Dent. 2003;89(5):427-35. doi:10.1016/S0022-3913(03)00158-6

5. van Meegen HG, Kalk W. Improvement of a removable complete denture by relining or rebasing. Ned Tijdschr Tandheelkd. 2011;118(11):545-51.

6. Haywood J, Basker RM, Watson CJ, Wood DJ. A comparison of three hard chairside denture reline materials. Part I. Clinical evaluation. Eur J Prosthodont Restor Dent. 2003;11(4):157-63. 
7. Archadian N, Kawano F, Ohguri T, Ichikawa T, Matsumoto N Flexural strength of rebased denture polymers. J Oral Rehabil. 2000;27(8):690-6. doi: 10.1046/j.1365-2842.2000.00552.x

8. Walker MP, Spencer P, David Eick J. Mechanical property characterization of resin cement after aqueous aging with and without cyclic loading. Dent Mater. 2003;19(7):645-52. doi:10.1016/S0109-5641(03)00008-3

9. Paranhos HF, Silva-Lovato $C H$, Souza RF, Cruz PC, Freitas KM, Peracini A. Effects of mechanical and chemical methods on denture biofilm accumulation. J Oral Rehabil. 2007;34(8):60612. doi: 10.1111/j.1365-2842.2007.01753.x

10. Orsi IA, Andrade VG. Effect of chemical disinfectants on the transverse strength of heat-polymerized acrylic resins submitted to mechanical and chemical polishing. J Prosthet Dent. 2004;92(4):382-8. doi:10.1016/j.prosdent.2004.07.015

11. Freire TS, Aguilar FG, Garcia Lda F, Pires-de-Souza Fde C. Colour stability ofdenture teeth submitted to different cleaning protocols and accelerated artificial aging. Eur J Prosthodont Restor Dent. 2014;22(1):24-7. doi: 10.1922/EJPRD_1237Souza04

12. Pinto JR, Mesquita MF, Nóbilo MA, Henriques GE. Evaluation of varying amounts of thermal cycling on bond strength and permanent deformation of two resilient denture liners. J Prosthet Dent. 2004;92(3):288-93. doi:10.1016/j.prosdent.2004.06.005

13. Craig RG, Powers JM. Materiais dentários restauradores. São Paulo: Santos; 2004.

14. Machado C, Rizzatti-Barbosa CM, Gabriotti MN, Joia FA Ribeiro MC, Sousa RL. Influence of mechanical and chemical polishing in the solubility of acrylic resins polymerized by microwave irradiation and conventional water bath. Dent Mater 2004;20(6):565-9. doi:10.1016/j.dental.2003.09.001

15. Gotusso MJ. Chemical surface treatment of acrylic resins. Rev Asoc Odontol Argent. 1969;57(10):359-61.

16. Stolf WI, Consani $S$, Ruhnke LA. Influência do polimento químico sobre a resistência ao impacto das resinas acrílicas. Rev Paul Odontol. 1985;7(6):26-30.

17. Leite VM, Pisani MX, Paranhos HF, Souza RF, Silva-Lovato $\mathrm{CH}$. Effect of ageing and immersion in different beverages on properties of denture lining materials. J Appl Oral Sci. 2010;18(4):372-8.doi: 10.1590/\$1678-77572010000400009

18. da Cruz Perez LE, Machado AL, Canevarolo SV, Vergani CE, Giampaolo ET, Pavarina AC. Effect of reline material and denture base surface treatment on the impact strength of a denture base acrylic resin. Gerodontology. 2010;27(1):62-9. doi: 10.1111/j.1741-2358.2009.00292.x

19 Zamperini CA, Machado AL, Vergani CE, Pavarina AC, Giampaolo $E T$, da Cruz NC. Adherence in vitro of Candida albicans to plasma treated acrylic resin. Effect of plasma parameters, surface roughness and salivary pellicle. Arch Oral Biol. 2010;55(10):763-70. doi: 10.1016/j.archoralbio.2010.06.015

20. Koch C, Bürgers R, Hahnel S. Candida albicans adherence and proliferation onthe surface of denture base materials. Gerodontology. 2013;30(4):309-13. doi: 10.1111/ger.12056

21. Braun KO, Mello JA, Rached RN, Del Bel Cury AA. Surface texture and someproperties of acrylic resins submitted to chemical polishing. J Oral Rehabil. 2003:30(1):91-8. doi: 10.1046/j.1365-2842.2003.00997.x

22. Araújo PM, Abreu D, Magalhães AEO. Propriedades das resinas acrílicas para bases de dentaduras submetidas ao polimento químico. Estomatol Cultura. 1972;6(2):39-54.

23. Arima T, Murata H, Hamada T. Properties of highly crosslinked autopolymerizing reline acrylic resins. J Prosthet Dent. 1995;73(1):55-9. doi: 10.1016/S0022-3913(05)80273-2

24. Wady AF, Machado AL, Vergani CE, Pavarina AC, Giampaolo ET. Impact strength of denture base and reline acrylic resins subjected to long-term water immersion. Braz Dent J. 2011;22(1):56-61. doi: 10.1590/S0103-64402011000100010

25. Finoti LS, Machado AL, Chaves CA, Pavarina AC, Vergani CE. Effect of long-term water immersion on the fracture toughness of denture base and reline resins. Gerodontology. 2012;29(2):e858-64. doi: 10.1111/j.1741-2358.2011.00573.x

26. Machado AL, Bochio BC, Wady AF, Jorge JH, Canevarolo SV Jr, Vergani CE. Impact strength of denture base and reline acrylic resins: An in vitro study. J Dent Biomech. 2012;3:1758736012459535.doi: 10.1177/1758736012459535

27. Rodrigues SA, Nunez Pantoja JM, Takahashi JM, Consani RL, Mesquita MF. Effect of chemical cleaning agents on the flexural strength of acrylic and hard denture line resins. Gen Dent. 2013;61(4):e1-4.

28. Goiato MC, Naves JC, Bressan RN, Santos DM, Fajardo RS, Fernandes AUR. Efeito de técnicas de polimento na porosidade e na dureza de resinas acrílicassubmetidas a termociclagem. Rev Odontol UNESP. 2006;35(1):47-52.

29. Rahal JS, Mesquita MF, Henriques GE, Nóbilo MA. Surface roughness of acrylicresins submitted to mechanical and chemical polishing. J Oral Rehabil. 2004;31(11):1075-9. doi: 10.1111/j.1365-2842.2004.01344.x

30. Dootz ER, Koran A, Craig RG. Physical property comparison of 11 soft denture lining materials as a function of accelerated aging. J Prosthet Dent. 1993;69(1):114-9. doi:10.1016/0022-3913(93)90250-R

Received on: 10/2/2015

Final version resubmitted on: 13/6/2015

Approved on: 25/8/2015 